\title{
PEMANFAATAN MODAL SOSIAL LOKAL DALAM MENGHADAPI PANDEMI COVID-19
}

\author{
Oleh: Rupita \\ Fakultas Ilmu Sosial dan Ilmu Politik, Universitas Tanjungpura Pontianak
}

\begin{abstract}
Abstrak
Pandemi Covid-19 menjadi wabah yang tidak hanya menyerang tubuh manusia, tetapi juga menumbangkan sistem penghidupan masyarakat ekonomi menengah ke bawah. Pada tulisan ini menyampaikan resiliensi masyarakat menengah bawah dengan memanfaatkan modal sosial lokal yang ada di lingkungan hidup mereka. Tulisan ini menggunakan pendekatan kualitatif deskriptif, dengan pendeskripsian data primer dan data sekunder. Mekanisme pengumpulan data lapangan dengan menggunakan protokol kesehatan. Temuan dalam tulisan ini menunjukkan bahwa dalam menghadapi perubahan ekonomi, masyarakat menengah ke bawah mampu mendapatkan alternative untuk bertahan hidup dengan memanfaatkan modal sosial lokal. Adapun Bantuan Langsung Tunai juga bermanfaat bagi masyarakat penerima bantuan. Hanya saja tidak semua masyarakat menengah ke bawah mendapatkan bantuan ini. Masyarakat memanfaatkan modal sosial untuk menopang ekonomi keluarga dalam menghadapi pandemi Covid-19.
\end{abstract}

Kata Kunci: Lokalitas, Modal Sosial, Pandemi Covid-19.

\section{PENDAHULUAN}

Pandemi COVID-19 merupakan wabah yang tragis di seluruh dunia. Tidak terkecuali negara Indonesia yang menghadapi pandemi ini. Novel coronavirus (yang kemudian disebut SARSCoV-2) berpusat di Provinsi Hubei, Republik Rakyat China (Velavan \& Meyer, 2020). Pada saat penelitian ini dilakukan, laporan World Health Organization (WHO, 2020) menunjukkan bahwa sudah 187.705 orang meninggal, dari 2.719.897 kasus positif yang terkonfirmasi karena virus yang ganas ini.

Pandemi Covid-19 membuat banyaknya pengaruh besar pada sektor kehidupan masyarakat (Obi, et al., 2020; Kashif, et al., 2020) sehingga hal ini berdampak pada masalah kemiskinan dan menjadi masalah yang menarik untuk didiskusikan dan dicarikan penyelesaiannya. Pada situasi pandemi Covid-19 hari ini, perempuan di wilayah pedesaan lebih rentan mengalami kemiskinan yang berlapis sebagai akibat double burden yang mereka perankan di dalam keluarga (Sender, 2002; Niko, 2019). Sejalan dengan hal ini, terdapat aktivitas menarik dari perempuan di Desa Runjai Jaya, Kecamatan Marau Kabupaten Ketapang dalam mencari strategi bertahan dalam ekonomi yang sulit pada masa pandemi Covid-19.

Berbagai strategi dilakukan untuk mengantasi dan membantu tunjangan bagi masyarakat miskin yang terdampak oleh pandemi Covid-19 ini. Salah satu strategi mungkin adalah dengan peningkatan modal sosial kelompok miskin dengan cara menyalurkan bantuan sosial pada pihak yang terdampak tersebut. Dalam hal ini juga adanya pelaksanan penyaluran bantuan sosial ini adalah bentuk pelaksanaan modal sosial di Indonesia yang artinya dapat membantu masyarakat miskin akibat terdampak Covid-19. 
Pemerintah Indonesia memberlakukan kebijakan Pembatasan Sosial Berskala Besar (PSBB) di beberapa daerah untuk memutus mata rantai penyebaran. Salah satu protokol kesehatan dalam implementasi PSBB adalah physical distancing yang mengharuskan masyarakat untuk menjaga jarak fisik dan membatasi aktivitas di luar rumah. Implementasi physical distancing berpengaruh terhadap perubahan kondisi ekonomi masyarakat (Muhyiddin, 2020).

Muhyiddin (2020) juga mengungkapkan bahwa data Sakernas menunjukkan bahwa masyarakat Indonesia mayoritas bekerja di sektor informal dan berdampak langsung terhadap implementasi kebijakan PSBB sehingga berpotensi mengalami kerentanan sosial yang berpotensi menjadikan posisi ketahanan ekonomi mengalami guncangan. Oleh karena itu, menurutnya diperlukan suatu upaya revitalisasi terhadap keberadaan home industry dengan berbasis pada modal sosial. Revitalisasi dilaksanakan sebagai upaya untuk mempertahankan perekonomian masyarakat. Ketahanan ekonomi masyarakat akan dengan mudah dicapai melalui penguatan modal sosial.

Dalam sebuah penelitian yang dilakukan oleh Suryahadi, Izzati, \& Suryadarma (2020) menyatakan bahwa sebagai akibat dari wabah Covid-19 di Indonesia, diproyeksikan bahwa ledakan orang miskin akan terjadi dalam situasi pandemi Covid-19 dengan peningkatan 12,4\% atau sekitar 8,5 juta orang akan menjadi miskin. Perkiraan peningkatan jumlah penduduk miskin di Indonesia disebabkan oleh penurunan yang signifikan dalam proyeksi pertumbuhan ekonomi Indonesia untuk tahun 2020. Kurniawansyah, dkk (2020) menyebutkan bahwa konsep penanganan sektor ekonomi di tengah pandemi Covid-19 ini semestinya dengan konsep kebijakan strategis yaitu kebijakan alokasi, kebijakan distribusi dan kebijakan stabilisasi.

Penanganan yang serius oleh pemerintah sudah cukup baik, namun hal ini belum berdampak pada pengurangan jumlah masyarakat miskin, baik di tingkat nasional maupun tingkat lokal pada masa pandemi Covid-19 ini. Program-program yang berasal dari dana APBD menyasar tidak tepat sasaran, kemudian dana yang disediakan dalam rangka penanggulangan kemiskinan masih relatif kecil jika dibandingkan jumlah penduduk miskin (Kertati, 2013).

Modal sosial memberikan kekuatan masyarakat lokal dalam menghadapi situasi pandemi Covid-19 yang sedang mewabah hari ini. Penguatan ini melalui implementasi norma-norma kolektif yang dapat menumbuhkan kepercayaan diantara anggota masyarakat sehingga jaringan sosial bisa terbentuk. Tidak dapat dipungkiri bahwa dibalik adanya pengelompokan disposisi yang berlainan dari kegiatan produksi atau kapitalisme itu terdapat kekuasaan beroperasi melalui pengembangan prasangka kultural yang dikembangkan oleh pihak luar. Dengan demikian budaya kemiskinan diperkenalkan kepada seluruh anggota masyarakat tersebut, sehingga mereka tidak menyadari terdapat sistem struktural yang dengan sengaja memiskinkan mereka. Apabila modal sosial ini melemah, makan potensi kemiskinan akan membayang-bayangi masyarakat dengan ekonomi menengah ke 
bawah.

Kemudian, apabila dilihat dalam praktik ekonomi lokal, dapat berwujud saling kerja sama pada tiap-tiap anggota komunitas lokal dalam menghasilkan barangbarang yang di produksi sendiri. Target pasar dari aktivitas produksi ini adalah masyarakat disekitarnya sehingga akan memunculkan jaringan dan rasa kepercayaan yang kuat antar anggota masyarakat. Kondisi ini akan mendorong masyarakat untuk tetap selalu waspada namun juga dapat berinovasi dan tetap produktif meski menghadapi berbagai kemungkinan menghadapi pendemi covid-19. Budastra (2020) menyebutkan bahwa hal yang penting diperhatikan pemerintah baik di tingkat pusat hingga lokal adalah adanya perlindungan bagi usaha kecil dan mikro serta terjaminnya ketersediaan makanan dan minuman siap konsumsi untuk penduduk rentan di tingkat desa.

Modal sosial merupakan energi kolektif masyarakat (atau bangsa) guna mengatasi problem bersama dan merupakan sumber motivasi untuk mencapai kemajuan ekonomi bagi masyarakat atau bangsa tersebut (Durkheim, 1973). Dalam hal ini, tidak cukup hanya memberikan bantuan modal dalam memberikan tunjangan hidup masyarakat miskin yang terdampak pandemi Covid-19 karena hal ini tidak dapat berjalan secara lama, dari hal tersebut pelaksanaan kegiatan pada kelompok usaha bersama adalah salah satu cara dalam meningkatkan produktivitas, tidak hanya dibimbing didalamnya, masyarakat juga dapat berkreativitas membuat keperluan yang sangat dibutuhkan masyarakat dalam hal terdesak dalam masa pandemi Covid19, masyarakat miskin yang terlibat dalam kelompok usaha bersama juga diberdayakan serta diberikan edukasi sesuai dengan protokol kesehatan pandemi Covid-19.

Pada dasarnya modal sosial diletakkan pada kebajikan-kebajikan sosial umum, artinya bahwa modal sosial dapat melebur pada kepercayaan dan faktor yang penting bagi kesehatan ekonomi sebuah negara, yang bersandar pada akar-akar kultural (Fukuyama, 1996). Penguatan modal sosial (Upe, et al., 2021) dalam menghadapi pandemi Covid-19 hari ini menjadi alternatif strategi untuk tetap bertahan di masamasa sulit. Hal ini membutuhkan menggalang solidaritas komunitas lokal untuk saling bahu-membahu satu dengan yang lainnya.

Makna modal sosial ini erat kaitannya dengan penguatan hubungan antar individu dengan individu maupun individu dengan kelompok sosial dalam bermasyarakat, termasuk tatanan kehidupan di dalam keluarga, maupun kelompok sosial (komunitas). Kekuatan hubungan sosial tercermin dari perilaku baik, rasa bersahabat, saling simpati, serta membina hubungan dan kerja sama yang erat diantara individu dalam keluarga yang membentuk suatu kelompok sosial dalam kehidupan bermasyarakat (Kushandajani, 2006).

Romli (2020) menyebutkan bahwa modal sosial dibutuhkan dalam rangka mengamankan ekonomi masyarakat lokal (mikro), terutama masyarakat yang mengembangkan industri rumah tangga. Ekonomi masyarakat lokal yang kuat mampu menguatkan ekonomi secara makro, sehingga ketahanan ekonomi keluarga 
dapat terjaga dengan adanya penghasilan yang berasal dari industri rumah tangga. Tulisan ini menggali lebih jauh mengenai modal sosial yang dimanfaatkan sebagai modal dasar masyarakat lokal bersolidaritas dalam menghadapi pandemi Covid-19.

\section{METODE PENELITIAN}

Metode dalam penelitian ini yaitu menggunakan pendekatan kualitatif deskriptif. Data dan informasi yang mendukung penulisan dikumpulkan dengan melakukan penelusuran pustaka, observasi dan wawancara tokoh. Data dan informasi yang digunakan dalam penelusuran pustaka yaitu data dari jurnal ilmiah, media elektronik, dan beberapa pustaka yang relevan. Adapun teknik pengumpulan data yang dilakukan yaitu: a) sebelum analisis data dilaksanakan, terlebih dahulu dilakukan studi pustaka yang menjadi bahan pertimbangan dan tambahan wawasan untuk penulis mengenai lingkup kegiatan dan konsep-konsep yang tercakup dalam penulisan; b) untuk melakukan pembahasan analisis dan sintesis data-data yang diperoleh, diperlukan data referensi yang digunakan sebagai acuan, dimana data tersebut dapat dikembangkan untuk dapat mencari kesatuan materi sehingga diperoleh suatu solusi dan kesimpulan.

Kegiatan penelitian ini dilaksanakan pada masyarakat Desa Runjai Jaya, Kecamatan Marau Kabupaten Ketapang, Kalimantan Barat. Pelaksanaan penelitian dengan mematuhi protokol kesehatan yang berlaku pada masa pandemi COVID-19. Kegiatan penelitian hanya berlangsung selama dua hari dalam proses pengumpulan data wawancara dan observasi di lapangan.Adapun tahapan yang dilakukan dalam penelitian ini sebagai berikut: (a) melakukan asesmen terhadap data sekunder; (b) melakukan wawancara melalui telepon dan tatap muka dengan informan; (c) memilih rentang waktu penelitian pada bulan Mei 2020; (e) menganalisis data, dan (f) menulis laporan hasil penelitian.

\section{PEMBAHASAN}

\section{Dampak Covid-19 pada Komunitas Lokal}

Masyarakat di Desa Runjai Jaya, Kecamatan Marau Kabupaten Ketapang saat ini membutuhkan perhatian pemerintah atas apa yang mereka alami saat ini, akibat dari dampak virus corona karena mereka sangat terdampak khusunya di bidang perekonomian. Ekonomi lokal yang mereka hadapi menjadi tidak stabil, dimana sumber pendapatan mereka menjadi terhambat, meskipun di Desa Runjai Jaya, Kecamatan Marau Kabupaten Ketapang masih tercatat belum ada kasus Covid-19.

Adapun Jumlah penduduk di Desa Runjai Jaya, Kecamatan Marau Kabupaten Ketapang berjumlah 80 kepala keluarga dan total jumlah penduduknya sebanyak 252 orang. Jumlah penduduka berdasarkan jenis kelamin yaitu perempuan berjumlah 130 orang sedangkan laki-laki berjumlah 122 orang, dengan rentang usia yaitu usia anakanak dengan usia 0-12 tahun berjumlah 40 orang, usia remaja dari umur 12-19 tahun sebanyak 60 orang, usia dewasa dari umur 19- 55 tahun sebanyak 132 orang, sedangkan yang dari umur 55-80 tahun 20 orang.

Adapun mata pencarian masyarakat di Desa Runjai Jaya, Kecamatan Marau 
Kabupaten Ketapang yaitu mayoritas penduduknya adalah petani. Meerka masih bergantung pada alam tempat dimana meraka berada, adapun petani di Desa Runjai Jaya, Kecamatan Marau Kabupaten Ketapang Hulu terbagi menjadi dua ada petani padi, petani karet dan petani (buruh) kelapa sawit.

Mengenai imbas dari pandemi Covid-19 ini banyak masyarakat di Desa Runjai Jaya, Kecamatan Marau Kabupaten Ketapang yang terkena imbasnya. Pendapatan ekonomi mereka semakin menurun di tiap harinya dan pengeluaran pun keluar setiap harinya untuk membeli kebutuhan untuk bertahan hidup di tengah pandemi ini. Isu-isu yang simpang siur menjadikan kekhawatiran masyarakat di Desa Runjai Jaya, Kecamatan Marau Kabupaten Ketapang atas betapa mengerikannya penyakit Covid-19 ini. padadasarnya menurut Eligh (2020) bahwa komunitas masyarakat lokal yang jauh dari wilayah akses kesehatan bisa jadi lebih rentan karena jauh dari akses dan informasi kesehatan yang baik.

Masih terdapat masyarakat yang kurang berpikiran terbuka dan jauh dari pengetahuan smart sosial media, maka dari itu banyak informasi yang tersebar tanpa kejelasan sumber yang pasti alias hoax. Sempat terdapat isu bahwa di Kecamatan Marau Kabupaten Ketapang sudah terapar virus corona dari orang yang bekerja di kota dan berinteraksi dengan penduduk kota. Masyarakat Desa Runjai Jaya, Kecamatan Marau Kabupaten Ketapang menjadi geger akan hal tersebut, banyak kekhawatiran yang berlebihan sampai informasi disebarkan di berbagai sosial media dan berdampak buruk sekali kepada orang yang dicurigainya, warga yang dicurigai langsung menggambil tindakan repid test dan hasilnya negatif.

Selain terdapat warga yang heboh dengan ketakutannya, ada pula warga yang tidak peduli adanya Covid-19 ini, dengan mereka masih bekerja seperti biasa tanpa protokol kesehatan seperi memakai masker dan sering mencuci tangan, berinteraksi dengan banyak orang tanpa pengaman dan bahkan membuat hajatan ditengah pandemi ini. Hal ini menandakan bahwa betapa pentingnya edukasi mengenai Covid-19 ini bagi warga di Desa Runjai Jaya, Kecamatan Marau Kabupaten Ketapang untuk mengetahui begaimana cara tertular dan cara mengatasinya.

Menghadapi pandemi Covid 19, pemerintah Indonesia mengeluarkan program BLT yang di anggarkan melalui dana Desa yang bertujuan untuk membantu masyarakat miskin, masyarakat yang rentan sakit ataupun masyarakat yang sakit menaun dan juga untuk masyarakat yang mengalami kesusahan ekonomi dalam menghadapi pandemi Covid 19. Mekanisme bantuan untuk masyarakat ini dilakukan oleh Kementerian Desa, Daerah Tertinggal dan Tranmigrasi juga dilakukan oleh Kementerian Sosial (Triyono, 2020). Pemerintah mengalihkan sebagian anggaran dana desa untuk program jaring pengaman sosial bagi warga yang terdampak Covid19. Bantuan langsung tunai (BLT) yang diambil dari dana desa ini akan menyasar 12,3 juta keluarga penerima manfaat (KPM) dengan indeks Rp 600 ribu per bulan selama tiga bulan,total anggarannya, sekitar Rp 21 triliun dari APBN.

Adapun dalam pemanfaatan modal sosial, pemerintah telah membuat program dengan menggunakan dana desa dengan memberikan Bantuan Langsung Tunai 
sebesar 600 ribu selama 3 bulan bagi masyarakat miskin maupun bagi masyarakat yang keadaan ekonominya terdampak pandemi Covid 19. Program bantuan langsung tunai (BLT) ini adalah sebuah kebijakan yang dikeluarkan oleh pemerintah yang memiliki tujuan dan alasan tertentu. Program tersebut muncul sebagai manifestasi adanya tindakan dari pemerintah yang berisikan nilai-nilai tertentu, yang ditujukan untuk memecahkan persoalan publik dengan memanfaatkan sumber daya yang tersedia.

Hari ini dengan situasi pandemi Covid-19, persoalan publik yang dimaksud adalah persoalan kemerosotan ekonomi lokal yang berpotensi menimbulkan kemiskinan. Secara umum kemiskinan adalah bilamana masyarakat berada pada suatu kondisi yang serba terbatas, baik dalam aksesibilitas pada faktor produksi, peluang/kesempatan berusaha, pendidikan, fasilitas hidup lainnya. Program Bantuan Langsung Tunai (BLT) dilatar belakangi upaya mempertahankan tingkat konsumsi Rumah Tangga Sasaran (RTS) sebagai akibat dampak virus Corona atau Covid-19. Adapun tujuan BLT yang tertuang dalam peraturan pemerintah adalah: 1) membantu masyarakat miskin agar tetap dapat memenuhi kebutuhan dasarnya; 2) penurunan taraf kesejahteraan masyarakat miskin akibat kesulitan ekonomi; 3) meningkatkan tanggung jawab sosial bersama.Tentunya peran pemerintah sangat diperlukan dalam suatu perekonomian.

\section{Pemanfaatan Modal Sosial Lokal: Strategi Bertahan Hidup di Tengah Wabah}

Perubahan sosial yang terjadi yang diakibatkan oleh pandemi Covid-19 dapat dikatakan sebagai perubahan sosial negatif karena membawa dampak-dampak yang signifikan terhadap kehidupan khususnya sosial, kesehatan, pendidikan bahkan ekonomi.Kebijakan yang diambil baik kebijakan berupa aturan ataupun program terus dilakukan oleh pemerintah dalam mengatasi risiko yang akan terjadi setelah pandemi Covid-19.

Pemanfaatan modal sosial dirasa lebih baik digunakan dalam kondisi new normal yang telah diberlakukan oleh pemerintah. Pemanfaatan modal sosial ini dapat membantu kondisi perekonomian mikro yang terdampak lebih besar akibat kondisi Covid-19. Sejalan dengan pendapat Niko (2020) yang menyebutkan bahwa dalam menghadapi pandemi Covid-19, komunitas lokal memiliki cara mereka sendiri untuk tetap bertahan dan resilien meski di tengah wabah, hal ini misalnya mereka saling bersolidaritas satu sama dengan yang lainnya.

Kegiatan masyarakat yang dilakukan oleh ibu-ibu PKK di desa Runjai Jaya, seperti membuat kerajinan tangan memungkinkan untuk menambah perekonomian keluarga mereka masing-masing. Karena kita tahu bahwa setelah adanya pandemi covid-19 ini, banyak yang kehilangan pekerjaan bahkan pemotongan gaji dari atasan dikarenakan kesulitan ekonomi. Pendapat Dao (2009) menyebutkan bahwa perempuan yang bekerja pada sektor pertanian di wilayah-wilayah desa pada negara berkembang berperan penting dalam memberdayakan diri dan mengurangi tingkat kemiskinan.

Pemerintahan desa berinisiatif untuk menambah perekonomian keluarga 
merekrut ibu-ibu PKK untuk sama-sama bergerak agar roda perekonomian terus berjalan meskipun banyak kendala. Dengan memulai usaha membuat kerajinan tangan seperti keranjang, keranjang ini banyak manfaat nya dan jika di jual akan memiliki nilai ekonomi. Inisiatif pembentukan kegiatan bersama ibu-ibu PKK dalam membuat kerajinan tangan demi memenuhi kebutuhan hidup sehari-hari dan menolong sesama yang terdampak covid-19 ini, di danai oleh pihak desa dan di bantu dengan pemungutan sumbangan dari orang yang lebih mapan. Seperti kutipan wawancara berikut ini:

Mengenai dana ya, untuk sekarang desa lah paling banyak mengeluarkan dana untuk kegiatan ini, tetapi ada juga pibak lain yang memberikan bantuan agar kegiatan ini berjalan lancar, misalnya seperti pemilik-pemilik toko yang ada di desa tersebut.

Dana yang berasal dari desa dan sumbangan donatur ini di gunakan untuk membeli kebutuhan dasar serta barang-barang yang digunakan untuk produksi dan pemasaran. Sementara itu bahan baku seperti rotan dan bambu tidak perlu membeli karena di hutan desa tersebut juga banyak tersedia rotan dan bambu. Pemanfaatan sumber daya alam lokal ini juga merupakan bentuk strategi bagi masyarakat di Desa Runjai Jaya.

Kemudian dalam pemasaran, masyarakat desa juga menjual hasil kerajinan mereka secara langsung. Namun, dalam situasi lain di bantu oleh anak-anak muda yang paham sosial media untuk ikut memasarkan produk mereka melalui sosial media. Dalam tulisannya Hardilawati (2020) disebutkan bahwa strategi bertahan untuk usaha kecil dan menengah dapat menggunakan strategi marketing melalui teknologi digital dan disertai dengan perbaikan kualitas produk yang dipasarkan.

Kemudian, pelaksanaan kegiatan pelatihan dilakukan sebelum memproduksi dan memasarkan produk, ibu-ibu ini dikumpulkan dalam satu ruanagn dengan tetap melaksanakan anjuran kesehatan dan pemerintahan, seperti memakan masker, cuci tangan sebelum masuk ruangan dan tetap menjaga jarak antara sau orang dan orang lainnya. Dan waktu pelaksanaannya pun tidak terlalu lama dan setelah kegiatan selesai para ibu-ibu dianjurkan untuk pulang ke rumah mereka masing-masing. Hasil kerajinan tangan para ibu-ibu misalnya seperti: bakul, keranjang, bisa juga membuat tikar,tas, serta tempat untuk bumbu-bumbu dapur lainnya.

Selama satu bulan kira-kira diadakan 3 kali pertemuan, dan menghasilkan beberapa kerajinan tangan, kemudian barang tersebut di jual ke pasar di kecamatan Marau dan dijual secara online juga, dan memang tidak sedikit orang yang menyukai kerajinan tangan tersebut. Berdasarkan wawancara dengan informan, didapatkan informasi sebagai berikut:

Program ini di buat karena melibat peluang yang dihasilkan juga cukup menjanjikean dan dana yang dikeluarkan pun tidak terlalu besar, dan ibu-ibu PKK pun sangat pandai dalam hal membuat kerajinan tangan. Dari bahan baku kita tidak perlu membeli ke toko lagi cukup mencari kebutan saja seperti Rotan dan Bambu banyak tersedia di hutan. Dan saya berpikir tidak ada salabnya memanfaatkan peluang yang ada, apalagi ditengah pandemi Covid-19 ini banyak yang kehilangan pekerjaan dan babkan untuk biaya 
makan sehari-hari saja merasa kesulitan. Jadi saya berinsiatif untuk merekrut ibu-ibu PKK untuk sama-sama bergerak memanfaatkan peluangyang ada.

Modal yang dikeluarkan untuk proses pembuatan hingga pemasaran kepada konsumen akan terus berputar sampai menghasilkan keuntungan dan tetap semangat dalam usahanya. Kemudian hasil dari penjualan ini tidak serta merta untuk pribadi melainkan dibagikan juga kepada mereka yang lebih membutuhkan, misalnya mereka yang kurang mampu (benar-benar miskin yang tidak mendapatkan bantuan pemerintah).

Bantuan yang diberikan pun dalam bentuk sembako, karena banyak pertimbangan jika diberikan dalam bentuk uang tunai langsung, salah satunya adalah mereka tidak memiliki transportasi untuk berbelanja di pasar yang lokasi nya cukup jauh dari desa, sehingga kesulitan untuk berbelanja kebutuhan pokok, maka dari itu bantuannya langsung diberikan dalam bentuk sembako saja. Hal ini sejalan dengan pendapat Amalia (2015) yang menyebutkan bahwa modal sosial pada dasarnya lebih menekankan pada kebersamaan dan energi sosial, dimana ini akan membangun kekuatan bagi mereka yang rentan untuk bersolidaritas secara sosial dalam mengatasi keterbatasan modal material.

Kegiatan usaha ini sangat membantu, khususnya bagi pemerintahan desa untuk mengurangi terjadinya kemiskinan atau bahkan tidak cukup uang untuk membeli makanan dan akhirnya menyebabkan masyarakat menyalahkan desa karena tidak adanya bantuan dari pemerintah. Bentuk modal sosial yang dilakukan oleh masyarakat ini merupakan bentuk solidaritas mereka bersama dalam bertahan hidup di tengah pandemi Covid-19. Pada dasarnya, keuntungan dari penjualan kerajinan tangan ini bukan dimanfaatkan secara individu, melainkan kolektif.

\section{PENUTUP}

Kegiatan produksi kerajinan tangan dari bambu dan rotan di desa Runjai Jaya menjadi salah satu kegiatan masyarakat khusus nya wanita. Kegiatan ini sangat mendukung untuk mengasah kemampuan atau skill para ibu-ibu agar berani mengekspresikan kerajinan tangan mereka, kegiatan ini sangat mendukung keberlangsungan ekonomi keluarga mereka karena pada awalnya para peserta akan melakukan pelatihan terlebih dahulu. Dari hasil produksi kerajinan tangan ini mereka memperoleh pendapatan yang nantinya bisa membantu masyarakat miskin dan kehilangan pekerjaan di lingkungan desa mereka. Pelaksanaan kegiatan perkelompok usaha bersama ini merupakan sebuah bentuk modal sosial yakni untuk mencapai tujuan bersama, jika dikerjakan sendri maka tidak ada kebersamaannya, tetapi jika dikerjakan secara bersama-sama maka akan terasa solidaritasnya. Apabila orang hanya bisa memikirkan diri sendiri, maka akan sulit untuk melewati masa-masa pandemic covid-19 ini, maka dari itu diperlukan kerjasama dari masyarakat dan pemerintahan untuk sama-sama bergotong royong dan saling membantu untuk saling meringankan kebutuhan hidup. 


\section{DAFTAR PUSTAKA}

Amalia, D. A. (2015). Modal Sosial dan Kemiskinan. Sosio Informa. 1(3), 310-323.

Budastra, I. K. (2020). Sosial Ekonomi Covid-19 dan Program Potensial untuk Penanganannya: Studi Kasus di Kabupaten Lombok Barat. Jurnal Agrimansion. 21(1), 48-57.

Dao, M., Q. Poverty, Income Distribution and Agriculture in Developing Country. Journal of Economic Studies. 36(2), 168-183.

Durkheim, E. (1973). Morality and Society. Chicago: University of Chicago Press.

Eligh, B. (2020). Hope and Pray that we Make it through: COVID-19 Underscores Vulnerability of Remote Communities.

Fukuyama, F. (1996). Trust: The social virtues and the creation of prosperity. New York: Simon \& Schuster.

Hardilawati, W. L. (2020). Strategi Bertahan UMKM di Tengah Pandemi Covid-19. Jurnal Akuntansi dan Ekonomika. 10(1), 89-98.

Kashif, M., Aziz-Ur-Rehman, Javed, M.K. \& Pandey, D. (2020). A Surge in CyberCrime during COVID-19. Indonesian Journal of Social and Environmental Issues (IJSEI), 1(2), 48-52.

Kertati, I. (2013). Analisis Kemiskinan Kota Semarang berdasarkan Data Pendataan Program Perlindungan Sosial (PPLS). Jurnal Riptek. 7(1), 27-38.

Kurniawansyah, H., Amrullah, A., Salahuddin, M., Muslim, M., \& Nurhidayati, S. (2020). Konsep Kebijakan Strategis Dalam Menangani Eksternalitas Ekonomi dari Covid-19 Pada Masyarakat Rentan di Indonesia. Indonesian Journal of Social Sciences and Humanities. 1(2), 130-139.

Muhyiddin. (2020). Covid-19, New Normal dan Perencanaan Pembangunan Indonesia. The Indonesian Journal of Development Planning. IV(2), 240252.

Niko, N. (2019). Kemiskinan Perempuan Dayak Benawan di Kalimantan Barat sebagai Bentuk Kolonialisme Baru. Jurnal Pemikiran Sosiologi. 6(1): 58-76.

Niko, N. (2020). Handling the Outbreak among the Indigenous People of Dayak Benawan. CSEAS NEWSLETTER, 78: TBC.

Obi, S. E., Yunusa, T., Ezeogueri-Oyewole A. N., Sekpe, S. S., Egwemi, E., \& Isiaka, A. S. (2020). The Socio-Economic Impact of Covid-19 on The Economic Activities of Selected States in Nigeria. Indonesian Journal of Social and Environmental Issues (IJSEI), 1(2), 39-47.

Romli, L. (2020). Covid-19 dan Modal Sosial. Pusat Penelitian Politik LIPI. Retrieved from: http://www.politik.lipi.go.id/kolom/kolom-2/politik-nasional/1401covid-19-dan-modal-sosial

Sender, J. (2002). Women's Struggle to Escape Rural Poverty in South Africa. Journal of Agrarian Change. 2(1), 1-49. 
Suryahadi, A., Izzati, R. A., \& Suryadarma, D. (2020). The Impact of COVID-19 Outbreak on Poverty: An Estimation for Indonesia. Jakarta, Indonesia: TheSMERU Research Institute.

Triyono, A. (2020). Kemensos Salurkan Bantuan Sembako dari Presiden RI dalam Rangka Penanganan Covid-19.Retrieved fromhttps://kemsos.go.id/kemensos-salurkanbantuan-sembako-dari-presiden-ri-dalam-rangka-penanganan-covid-19

Upe, A,. Ibrahim, Z., Arsyad, M., Sumandiyar, A., Jabar, A.S. 2021. Strengthening of Social Capital through Penta Helix Model in Handling Covid-19 Pandemic. International Journal of Pharmaceutical Research. 13 (1), 4243-4248.

Velavan, T. P., \& Meyer, C. G. (2020). The COVID-19 epidemic. Tropical Medicine and International Health. Doi: 10.1111/tmi.13383

World Health Organization. (2020). Coronavirus disease (COVID-19) Pandemic. Retrieved from: https://www.who.int/emergencies/diseases/novel$\underline{\text { coronavirus-2019 }}$ 